\title{
InSTITUSi PersaudaraAn Sufi
}

\author{
Abdul Malik
}

\section{Abstract}

Change of the personal mysticism to be an institute or league related from the development and spreading of the mysticism itself. Therefore by the dissemination of the mysticism invited many more people wanted to learn about the mysticism (tasawuf). Beside that they also met the knowledgeable and experienced people in mysticism which guided them. How ever, learning with the teaching method that was arranged base on experience of a practical science was a must, because of those two significances, the tasawuf/mysticism teacher formulated a learning tasawuf system based on his experience himself. Therefore, that learning system was a distinctive feature of this institution which differenciated from other institutions.By that simplest methode, a suficmystic relationship was developing between teacher and student, then the students wanted to keep the teacher's doctrine. Consequently, it created a distinctive style of this relationship transforming their scientific. So, this short papper will conferred about what kind of institution transforming theirscientific

Keywords : sufi, institution, transformation, teacher, student

\section{A. Pendahuluan}

Peralihan tasawuf yang bersifat personal menjadi sebuahlembaga tidak terlepas dari perkembangan dan perluasan tasawuf itu sendiri. Dengan semakin luasnya pengaruh tasawuf itu, semakin banyakorang yang berhasrat mempelajari tasawuf. Untuk itulah mereka menemui orang yang memiliki pengetahuan dan pengalaman yang luas dalam pengaläman tasawuf yang dapat menuntun mereka, sebab belajar dari seorang guru dengan metode mengajar yang disusun berdasarkan pengalaman dalam suatu ilmu yang bersifat praktikal adalah suatu keharusan. Oleh karena bertemunya dua kepentingan itulah, kemudian seorangguru tasawuf memformulasikan suatu sistem pengajaran tasawuf yang berdasarkan pengalamannya sendiri. Sistem 
pengajaran itulah yang kemudian menjadi ciri khas bagi institusi ini yang membedakannya dari institusi yang lainnya.

Dari bentuk yang paling sederhana itu, persaudaraan sufi berkembang dari hubungan yang terjadi antara syaikh dan muridnya, kemudian muncul keinginan dari para muridnya untuk melestarikan ajaran syaikhnya sehingga menimbulkan gaya tersendiri dari persaudaraan ini dalam menstranformasikan keilmuwan mereka. Untuk itu dalam tulisan ini akan dibahas bagaimana bentuk institusi tasaawuf dalam menstransformasikan keilmuwan mereka.

\section{B. Sejarah Munculnya Persaudaraan Sufi}

Sebelum dibahas tentang karakteristik institusi sufi ini, maka perlu juga diketengahkan bagaimana awal mula persaudaraan ini muncul sehingga akan dapat dimaklumi mengapa mereka (persaudaraan ini) mempunyai inisiatif membentuk sebuah institusi.

Term sufi sebenarnya baru dikenal pada penghujung abad II $\mathrm{H}$, sebagai perkembangan lanjut dari kesalehan asketis atau para zahid yang mengelompok di serambi mesjid Medinah. Dalam perjalanan kehidupan kelompok ini lebih menghususkan untuk beribadah dan mengembangkan kehidupan rohaniah dengan mengabaikan kenikmatan duniawi. Mungkin jika disebut secara kasar, maka kelompok ini merupakan oposisi dari pemerintah yang gila akan kehidupan duniawi.

Secara garis besar ada 3 faktor yang menimbulkan gerakan para sufi ini muncul. (1) adalah karena corak kehidupan yang profan dan hidup kepelisiran yang diperagakan oleh umat Islam terutama para pembesar negeri dan para hartawan. Dari aspek ini, dorongan yang paling deras adalah sebagai reaksi terhadap sikap glamour dari kelompok elit dinasti penguasa. Protes tersamar ini mereka lakukan dengan gaya murni etis, pendalaman kehidupan spiritual dengan motivasi etikal. Kelompok ini sebenarnya ingin menjadi kelompok yang netral, namun belakangan para sarjana Barat menyebutnya sebagai oposisi ulama Madinah.(lihat Montgomery Watt,1985:37) (2) timbulnya sikap apatis sebagai reaksi maksimal kepada radikalisme kaum khawarij dan polarisasi politik yang ditimbulkannya. 
Kekerasan pergulatan politik pada masa itu, menyebabkan orang-orang yang ingin mempertahankan kesalehan dan ketenangan rohaniah, terpaksa mengambil sikap menjauhi kehidupan kehidupan masyarakat ramai untuk menyepi dan sekaligus menghindarkan diri dari keterlibatan langsung dalam pertentangan politik. Sikap demikian melahirkan ajaran 'uzlah yang dipelopori oleh Surri al-Saqathi (w. $253 \mathrm{H})$. (3) adalah karena corak kodifikasi hukum Islam dan perumusan ilmu kalam yang rasional sehingga kurang bermotivasi etikal yang menyebabkan kehilangan moralitasnya, menjadi semacam wahana tiada isi atau semacam bentuk tanpa jiwa. Formalitas paham keagamaan dirasakan semakin kering dan menyesakkan ruh al-Din yang menyebabkan terputusnya komunikasi langsung suasana keakraban personal antara hamba dan penciptanya. Kondisi hukum dan teologi yang kering tanpa jiwa itu, karena dominasinya posisi moral dalam agama, para zuhhad tergugah untuk mencurahkan perhatian terhadap moralitas, sehingga memacu pergeseran asketisme kesalehan kepada tasawuf. Doktrin al-Zuhd misalnya, yang tadinya sebagai dorongan untuk meningkatkan ibadah semata-mata karena takut siksa neraka, bergeser kepada demi kecintaan dan semata-mata karena Allah agar selalu dapat berkomunikasi dengan-Nya. Konsep tawakal yang tadinya berkonotasi kesalehan yang etis, kemudian secara diametral dihadapkan kepada pengingkaran kehidupan yang profanistik disatu pihak dan konsep sentral tentang hubungan manusia dengan Tuhan, yang kemudian populer dengan doktrin al-Hubb. Doktrin al-Hubb merupakan tingkat akhir sebelum ma'rifat yang berarti mengenal Allah secara langsung melalui pandangan batin.(Rivay Siregar, 2000:40) Menurut sebagian sufi, ma'rifat Allah adalah tujuan akhir dan sekaligus merupakan tingkat kebahagiaan paripurna yang mungkin dicapai oleh manusia didunia ini.

\section{Terbentuknya Sebuah Institusi Persaudaraan Sufi}

Begitulah upaya para sufi untuk mendapatkan jenjang-jenjang yang menurut mereka harus didapatkan.Untuk mempermudah proses itu, sebagian para sufi mempunyai ide untuk membangun sebuah lembaga yang dirasakan perlu dalam mentransmisikan keilmuwan mereka, selain itu juga 
lembaga ini akan bermanfaat untuk melestarikan ajaran-ajaran dari para guru terdahulunya. Lembaga-lembaga ini memiliki nama yang khas sesuai dengan daerahnya masing-masing. Misalnya Ribat, Khanaqah serta Zawiyah.

Lembaga ini menjadi pusat latihan bagi para murid yang belajar ke tariqat tertentu, bagaikan sebuah asrama yang didirikan untuk menampung para muridnya. Sifat sufisme adalah evolusioner, untuk itu suatu lembaga sufi niscaya tidak mungkin mengambil suatu bentuk permanen yang kaku. Di tempat-tempat tertentu dan dibawah guru-guru individual, sekolahsekolah muncul dan melaksanakan suatu kegiatan yang dimaksudkan untuk meningkatkan kebutuhan manusia terhadap penyempurnaan pribadi. Sekolah-sekolah (seperti sekolah Rumi dan Data Ganj Bakhsh, sebagai contoh) menarik minat banyak orang yang bukan Muslim, meskipun sekolahsekolah sufi sejak kemunculan Islam, selalu dipimpin oleh orang-orang yang berasal dari tradisi muslim.

Memang jika dilihat dari sejarahnya, sufisme telah mencapai usia dewasanya sebagai sebuah gerakan sosial, dan benar-benar telah mengembangkan sebuah metafisika sufi dan mengintegrasikan pemikiran dan praktik sufi dengan bentuk lain dari keyakinan dan peribadatan Islam. Sejak awal pertumbuhannya hingga pertengahan abad ke-sepuluh kaum sufi telah mencapai identitas yang koheren sebagai satu diantara kelompok Muslim yang mencari kebenaran Islam. Meskipun sufisme benar-benar bersifat individual, tempat-tempat pertemuan kaum Sufi memberi mereka sebuah identitas kolektif. Ribaths yang semula merupakan tempat tinggal bagi prajurit Muslim yang berjaga-jaga di wilayah perbatasan dengan imperium Bizantium di Afrika Utara; di perbatasan Iran Timur mereka menampung prajurit sukarelawan untuk jihad (perang suci). Dalam modelnya di wilayah perbatasan tersebut, ribaths serupa dengan tempat-tempat pertemuan sebagaimana yang terdapat di Abadan, Damascus, dan Ramla pada pertengahan abad kedelapan. Sebagai tiruan terhadap tradisi kependetaan Kristen, terdapat sejumlah gua sebagai tempat pertemuan sufi di khurasan. Namun, perlu diketahui bahwa para Sufi sendiri sama sekali tidak pernah menganggap dirinya bertujuan menjalankan suatu tugas, yaitu tugas mentransendentalkan bentuk-bentuk lahiriyah dan fakta keagamaan yang lain atau pemerolehan pengetahuan agama lain dengan menjalankan tugas 
tersebut. Mungkin sulit untuk menjelaskan dengan istilah yang lebih sederhana dari agama formal bahwa pengalaman mistik adalah tunggal. Bahwa ada kesamaan yang lestari. Paling tidak orang hanya dapat memahami fakta tersebut menurut pengertian yang lazim, karena fakta pengalaman sufi dan aliran mistik yang lainnya bidang kajiannya adalah psikologi, bukan bidang akademis. (Idries Shah, 2000:481)

Term khanaqah sendiri muncul pada akhir abad ke-9 dan digunakan secara luas untuk pengertian tempat tinggal sufi di Khurasan dan Transaxonia. Kata tersebut digunakan untuk pemukiman orang-orang pendatang tanpa sebuah afiliasi bersama kepada seorang guru, tetapi khanaqah digunakan untuk tujuan yang bersifat sekteraian oleh seorang tokoh mistik dan teologi Muhammad Ibn Karram(806-869). Dari khanaqah ini lantas para sufi menyusun aturan-aturan peribadatan dan sebuah kitab hukum perilaku dan mengatur hukum komunal khanaqah.( Perlu diketahui bahwa yang pertama kali menyusun aturan-aturan peribadatan itu adalah $\mathrm{Abu}$ Sa'id ibn Abi al-Khair (967-1049).(Lihat: Ira M Lapidus, 1999:258) Term yang sama digunakan di Mesir Tengah, dimana khanaqah dibentuk sebagai pusat budaya dan teologi dari para sufi. Pemerintah setempat memberikan subsidi bagi kemanfaatan pengaruh lembaga itu. Kata zawiyah (pojok), digunakan untuk unit yang lebih kecil, menyerupai tempat tinggal untuk menyepi (solitair) dari para Syaykh. Istilah ini juga dihubungkan dengan tapal batas istana para tentara yang didirikan oleh Islam, selain itu juga mengacu pada pusat dari sebuah persaudaraan. (Annemarie Schimmel, 1975:232)

Di Makkah sendiri term zawiyah atau tekye digunakan sebagai gedung pertemuan para pengikut tariqat disana, yang beberapa diantaranya dihuni banyak banyak pengikutnya.(Martin Van Bruinesen, 1995:33)

\section{Para Sufi Menemukan Konsep Institusi}

Demikianlah akhirnya, sebuah persaudaraan itu secara tidak langsung para sufi telah membuat sebuah sistem institusi, yaitu sistem institusi yang terbentuk secara spontan karena ada keinginan dari para muridnya untuk melestarikan ilmu guru terdahulunya. Sebagian para sufi yang menginginkan 
sebuah transmisi keilmuwan harus berupaya berguru pada seorang syaikh yang mumpuni dan dapat dipertanggungjawabkan keilmuwannya, artinya ilmu mereka haruslah bersambung dengan ilmu Rasulullah saw. Istilah bersambung ini kemudian dikenal dengan silsilah. Silsilah merupakan bentuk dari upaya dari para syaikh untuk memperoleh sebuah ilmu yang legal langsung dari Rasulullah, semacam pencarian sanad yang dilakukan oleh para ahli hadis. Menurut J. Spencer Trimingham, silsilah adalah mata rantai spiritual dalam tariqat yang bersambung kepada Nabi Muhammad saw hingga ke syaikh yang sekarang. Dengan keterikatannya pada silsilah inilah murid yang baru ditahbiskan punya sarana untuk menempuh dan melaksanakan perjalanan menuju Allah dibawah lindungan ilahi. (J. Spencer Trimingham, 1973:186).

Muhammad, dalam silsilah bagaikan kartu nama dan legitimasi seorang guru untuk menunjuk ke cabang tariqat mana ia termasuk dan bagaimana hubungannya dengan guru-guru tariqat lainnya. (Martin Van Bruinesen, 1998:48).

Idealnya, setiap guru yang tercantum dalam silsilah ini seharusnya mendapatkan ilmu dari Nabi saw melalui guru-guru sebelumnya. Namun, kenyataannya tidak selalu demikian, kadang-kadang dua orang berurutan dalam silsilah dapat saja tidak pernah bertemu, karena yang pertama wafat sebelum kedua lahir atau karena mereka tinggal di negeri yang berjauhan sekali. Sebagian para ahli hadis menolak, karena menurut mereka hadis yang sanadnya terputus, tidak muttasil dinamai munqati'dan bila terputus sanadnya dua orang/rawi atau lebih berturut-turut, maka hadis itu dinamai $m$ u'dal, karena itu hadisnya lemah (daif) dan tidak dapat dijadikan hujjah. (Lihat: M. Ajjaj al-Khatib, 1989:339-340).

Sebagian sufi menolak silsilah semacam itu dan menganggapnya palsu, tetapi sebagian besar tidak menolak kemungkinan bahwa seoarng wali menerima pelajaran dari guru yang mendahuluinya bukan lewat komunikasi secara langsung, tetapi lewat komunikasi spiritual, yaitu melalui pertemuan dengan wujud ruhaniyahnya. Dalam silsilah, hubungan demikian itu kadang-kadang disebut barzakhi atau uwaisi. (Barzakhi, karena pembaiatannya ternyata berasal dari alam barzakh, alam antara, yaitu tempat bersemayamnya ruh orang meninggal sebelum datangnya hari kebangkitan. Istilah 
uwaisi berasal dari uwais al-Qarani, orang dari yaman yang sezaman dengan Nabi, dan tak pernah berjumpa ketika beliau masih hidup tetapi dipercaya telah diislamkan oleh Nabi setelah beliau wafat.

Untuk lebih berhati-hati lagi dalam mentransformasikan keilmuwannya para sufi melakukan upacara bay'ah. Bay'ah merupakan ikrar atau ritus pentahbisan seorang murid masuk dalam suatu tariqat sufi. Layaknya seorang sarjana yang akan lulus dari sebuah institusi pendidikan. Ikrar ini sesungguhnya adalah ikrar antara Allah dan hamba-Nya, yang senantiasa mengikat sang murshid dan murid secara bersamaan. Di dalam bay'ah ini ada momen suci ketika energi spiritual (barakah) (Barakah merupakan kekuatan sufi untuk menembus secara batin signifikansi-nominal dari makna, barakah memiliki kualitas magis. Salah satu kualitas magis ini adalah, barang siapa yang diberi barakah maka ia telah diubah karena dampak dari orang ini secara spiritual tercurahkan. (Lihat: Shah:2000)

Dalam mata rantai spiritual (silsilah) dialirkan dari murshid kepada murid. Ini memungkinkan seorang murid untuk menempuh perjalanan dengan aman dan selamat di bawah perlindungan dan pertolongan ilahi. (Amstrong: 35)

Ada suatu interaksi ganda yang saling terkait dalamperjanjian tersebut, suatu hubungan berdasar perjanjian yang diresmikan melalui bay'at ini. Dalam konjungtur inilah seorang salik diperbolehkan menyebut dirinya sendiri sebagai murid. Telah berlaku pada semua tariqat bahwa seseorang hanya dapat menjadi anggota tariqat setelah melalui per-bay'at-an. Bentuk dari upacara tersebut bermacam-macam di tempat yang berbeda, tetapi seperti biasa kebanyakan ritus yang demikian menyangkut kematian dan kelahiran secara simbolik. Mula-mula sang murid harus melakukan taubat, yaitu dengan mengingat segala dosa di masa lampau, memohon pengampunan dan bertekad untuk tidak mengulangi lagi semua kebiasaan jelek yang diperbuatnya dulu. Pada bagian inti upacara itu, sang murid menyatakan sumpah setia kepada syaikh-nya, setelah itu murid diperbolehkan turut serta dalam ritual-ritual bersama dalam tariqat itu. (Bruinesen,1998)

Setelah melakukan bay'ah, maka calon sufi mendapatkan ijazah dari para syaikh-nya. Layaknya seorang guru yang menggunakan metode dalam proses belajar mengajar, para sufi juga menerapkan metode yang dikenal 
dengan rabitah. Rabitah adalah sebuah metode dari para sufi dalam mentransmisikan keilmuwan mereka. Hal ini mereka lakukan untuk melihat kemampuan murid yang belajar supaya mereka dapat menjalankan keilmuwannya sesuai dengan yang diharapkan. Dalam realitasnya para murid yang belajar mempunyai kemampuan yang berbeda-beda, ada yang harus dibimbing langsung oleh sang guru, ada juga yang langsung dibiarkan oleh sang guru untuk melakukan kontemplasi dalam ruangan khusus. Untuk itulah metode rabitah digunakan oleh para murshid kepada para muridnya terutama yang masih awam akan ilmu yang diajarkan para murshid tersebut, karena dalam metode ini para murid diharuskan menggambarkan (visualization) rupa sang guru hal itu menandakan bahwa murid harus dalam pengawasan sang guru. Jika dianalogkan dengan sistem pengajaran formal, maka siswa yang masih dalam pengawasan sang guru merupakan siswa yang awam, begitu juga dalam institusi ini. Dalam setiap tariqat sendiri mempunyai konsep rabitah yang bervariasi, namun rabitah seringkali muncul dalam bentuk seberkas cahaya yang memancar dari sang murshid.

Muhammad Amin al-Kurdi sendiri memberikan definisi bahwa rabitah murshid adalah menghadapkan hati murid kepada hati gurunya, dan menghadirkan rupa sang guru dalam imajinasinya walaupun secara fisik sang guru tidak hadir. Dengan asumsi bahwa hati sang guru itu ibarat sebuah pancuran yang melimpah dari lautan yang luas ke dalam hati murid yang murabit.Untuk menyauk berkah darinya, karena sang guru adalah mediator untuk sampai kepada Tuhan. (Muhammad Amin Kurdi, 1994:444).

Memang untuk dapat memahami hubungan antar guru dan murid dalam sufisme hanya dapat dipahami melalui sistem pengajarannya. Di satu sisi ajaran sufi berada diluar konsep ruang dan waktu. Hal ini sesuai dengan unsur dasar dalam sufisme, bahwa guru dan murid mempunyai status yang sama. Disisi lain ajaran sufi meliputi semua aspek kesadaran manusia yang terdiri dari pengalaman, kehidupan dan konsep benda-benda. Suatu bentuk interaksi yang khas menimbulkan suatu transformasi. Maka dari itu, hubungan tersebut pada dasarnya jauh melampoi ruang lingkup belajar mengajar formal.( Shah, 2000: 463).

Tujuan akhir dari institusi ini adalah ma'rifat kepada Allah untuk itu para murid diharuskan melakukan Dhikr (ingat) kepada Allah. Dhikr 
merupakan amalan dasar dalam menempuh jalan sufi dan bisa dilakukan secara sendirian maupun bersama-sama.(Armstrong, sufi: 41)

Begitulah sistem yang digunakan persaudaraan ini, yang nampaknya banyak diadopsi oleh para pemerhati pendidikan dalam mengembangjan program pendidikan yang selama ini belumberhasil, misalnya sistem asrama yang sekarang menjadi trend dalam dunia pendidikan. Sistem itu tak lain adalah adopsi dari sistem ribaths, kahanaqah dan zawiyan yang dipakai oleh para sufi untuk menimba ilmu. Wa Allah A'lam bi al-Sawab.

\section{E. Penutup}

Perjalanan sufi yang pada mulanya bersifat individual akhirnya menjadi sebuah institusi melalui proses yang panjang dan melelahkan, karena ada ide dari sebagian murid untuk melestarikan ajaran para gurunya. Akhirnya terbentuklah sebuah institusi persaudaraan yang sangat unik. Keunikan ini mereka tampakkan dalam menstranformasikan ilmu mereka. Misalnya: dengan sistem barakah yang ternyata membuat para muridnya berupaya untuk memanfaatkan betul sistem ini. Mungkin bisa dikatakan bahwa barakah merupakan suatu siasat dari para guru agar para muridnya selalu taat pada mereka.

Namun, secara garis besar sistem yang ada dalam persaudaraan ini sangat unik dan perlu dikaji bahkan mungkin diadopsi kedalam sistem pendidikan yang modern jika perlu. Memang akhir-akhir banyak pemerhati pendidikan tampaknya juga banyak mengadopsi sistem kelembagaan ini, misalnya saja sistem asrama yang sekarang menjandi trend dikalangan dunia pendidikan sekarang. Sistem itu sebenarnya diadopsi dari institusi semisal Ribaths, kahanaqah ataupun zawiyah. 


\section{DAFTAR PUSTAKA}

Al-Khatib, M.Ajaj. 1989. Usul al-Hadith. Beirut: Dar al-Fikr.

Amin Kurdi, Muhammad, 1994. Tanwir al-Qulub Fi Mu'amalat 'Allam alGhuyub. tt: Dar al-Fikr.

Haeri, Fadhlala, 2000. Jenjang-Jenjang Sufisme, terj. Ibnu Burdah \& Shohifullah. Jogjakarta: Pustaka Pelajar.

M. Lapidus Ira, 1999. Sejarah Sosial Umat Islam bagian I \& II, terj. Ghufron A. Mas'adi Jakarta: P'T Raja Grafindo Persada.

Schimmel, Annemarie, 1975. Mystical Dimensions Of Islam. Chapel Hill: The University of North Carolina Press.

Shah, Idries. Mahkota Sufi, Dunia Ekstra Dimensi, terj. Hidayatullah \& Roudlon. Surabaya: Risalah Gusti, 2000

Siregar, Rivay. 2000. Tasauuf dari Sufisme Klasik ke Neo-Sufisme. Jakarta: RajaGrafindo Persada.

Trimingham, J Spencer., 1973. The Sufi Orders In Islam. London: Oxford University Press.

Van Bruinesen, Martin., 1995. Kitab Kuning Pesantem dan Tarekat, TradisiTradisi Islam di Indonesia. Bandung: Mizan.

Van Bruinesen, Martin., 1998. Tarekat Naqsyabandiyah di Indonesia. Bandung: Mizan.

Watt, Montgomery., 1985. Islamic Philosophy and Theology. Edindburgh: Edindburgh University Press. 